\title{
Cigarette smoking and parity as risk factors for the development of symptomatic gall bladder disease in women: results of the Royal College of General Practitioners' oral contraception study
}

\author{
F E Murray, R F A Logan, P C Hannaford, C R Kay
}

\begin{abstract}
The effects of cigarette smoking and parity on the development of symptomatic gall bladder disease remain controversial. These relations have been examined in a cohort of 46000 women followed for up to 19 years during the Royal College of General Practitioners' (RCGP) oral contraception study. During follow up, 1087 women were recorded as experiencing their first ever episode of symptomatic cholelithiasis (International Classification of Diseases, 8th revision (ICD-8) 574) or cholecystitis (ICD-8 575). Smokers were more likely to develop symptomatic gall bladder disease than non-smokers (relative risk 1.19; $95 \%$ confidence intervals $(95 \% \mathrm{CI}) 1.06$ to 1.34 ) and there was a significant trend with the number of cigarettes smoked daily (test for trend $\left.\chi^{2}=7.58, p<0.01\right)$. This relation was most apparent among never users of oral contraceptives, although similar trends were found among current and former users. A significant direct relation between symptomatic gall bladder disease and parity was also found (test for trend $\chi^{2}=21.89, p<0.001$ ). When all were examined together a trend of increasing risk with lower social class was also found (test for trend $\chi^{2}=5.72, p=0.02$ ). Current users of oral contraceptives had a moderately increased risk of symptomatic gall bladder disease (relative risk $1 \cdot 15 ; 95 \% \mathrm{CI}$ 0.99 to 1.34 ), unlike former users (relative risk $1.03 ; 95 \%$ CI 0.90 to $1 \cdot 18$ ). These results suggest that smoking and parity are important risk factors for the development of symptomatic gall bladder disease in women.

(Gut 1994; 35: 107-111)
\end{abstract}

Department of Therapeutics F E Murray

Department of Public Health Medicine and Epidemiology

R F A Logan

Royal College of General Practitioners

Manchester Research

Unit, Manchester

PC Hannaford

C R Kay

Correspondence to:

Dr R F A Logan, Departments of Public Health Medicine and Epidemiology, University

Hospital, Nottingham NG7 2UH.

Accepted for publication 19 May 1993
It is currently thought that cholesterol gall stones arise because of a triple hepatobiliary defect: cholesterol supersaturation of gall bladder bile, reduction gall bladder contractility, and increased rate of cholesterol nucleation, probably due to mucin glycoprotein hypersecretion. 12

Two recent case-control studies have suggested that smoking might protect against gall stone disease.$^{34}$ Both found a halving in risk of gall stone disease for smokers compared with non-smokers. Previous reports have indicated, however, that smoking is associated with an increased risk of gall stone disease..$^{5-7}$

Evidence for a positive association between parity and gall bladder disease is also contradictory, notwithstanding many studies of this relation. ${ }^{8}$ Pregnancy could affect each of the processes involved in gall stone formation. For example, progesterone impairs gall bladder contractility, ${ }^{9}$ and oestrogens may increase cholesterol saturation of bile ${ }^{10}$ and gall bladder prostaglandin synthesis, " and thus possibly mucin secretion by the gall bladder mucosa. A previous report from the Royal College of General Practitioners' (RCGP) oral contraception study suggested that the pill accelerated the development of symptomatic gall stone disease in women prone to the disease. ${ }^{12}$

This report has used further data from the RCGP oral contraception study to examine the influence of smoking and parity on the development of gall stone disease.

\section{Methods}

The organisation and methods used in the RCGP study have been described in detail elsewhere..$^{12}$ Briefly, over a 14 month period starting in May 1968, 1400 general practitioners throughout the United Kingdom recruited 23000 women who were using oral contraceptives and a similar number of women who had never used these preparations. The two groups were age matched and all women were married or living as married. Data on smoking habit and social class were collected at recruitment, at which time $48 \%$ of pill users smoked compared with $42 \%$ of the controls. Social class was based on the occupation of the women's husband. Every six months since recruitment, the general practitioners have supplied information about any use of hormonal preparations including oral contraceptives, any pregnancies, any operations, and all newly presenting episodes of illness. These results relate to data available at April 1987, by which time about $65 \%$ of subjects were no longer under observation, mainly because they have moved from the recruiting doctors' practice.

All women who experienced their first ever episode of symptomatic cholelithiasis (International Classification of Diseases, 8th revision (ICD-8 code 574) or cholecystitis (ICD-8 code 575) were included in this analysis. For the 108 women with both conditions, only the first episode was counted. The diagnosis was that given by the reporting general practitioner, and each event was categorised according to the woman's contraceptive state at the time of the event. Events occurring during pregnancy were excluded, together with the related periods of observation.

The incidence rates were indirectly standard- 
TABLE I Crude and standardised rates (per 1000) of reported first episode of gall bladder disease (ICD-8 574 or 575) by use of oral contraceptives and age

\begin{tabular}{|c|c|c|c|c|c|c|c|c|}
\hline \multirow[b]{2}{*}{$\begin{array}{l}\text { Age at diagnosis } \\
(y)\end{array}$} & \multicolumn{2}{|l|}{ Never users } & \multicolumn{2}{|l|}{ Former users } & \multicolumn{2}{|c|}{ Current users } & \multicolumn{2}{|l|}{ All women } \\
\hline & $\begin{array}{l}\text { Crude rate } \\
\text { (No) }\end{array}$ & $\begin{array}{l}\text { Standardised } \\
\text { rate }^{\star}\end{array}$ & $\begin{array}{l}\text { Crude rate } \\
(\mathrm{No})\end{array}$ & $\begin{array}{l}\text { Standardised } \\
\text { rate }^{\star}\end{array}$ & $\begin{array}{l}\text { Crude rate } \\
\text { (No) }\end{array}$ & $\begin{array}{l}\text { Standardised } \\
\text { rate }^{\star}\end{array}$ & $\begin{array}{l}\text { Crude rate } \\
\text { (No) }\end{array}$ & $\begin{array}{l}\text { Standardised } \\
\text { rate }\end{array}$ \\
\hline $\begin{array}{r}<24 \\
25- \\
30- \\
35- \\
40- \\
45- \\
50- \\
>50\end{array}$ & $\begin{array}{l}1 \cdot 37(12) \\
2 \cdot 81(66) \\
1.95(65) \\
2 \cdot 19(84) \\
2 \cdot 06(71) \\
2 \cdot 81(68) \\
2 \cdot 82(36) \\
2 \cdot 12(13)\end{array}$ & $\begin{array}{l}1 \cdot 62 \\
3 \cdot 08 \\
2 \cdot 04 \\
2 \cdot 25 \\
2 \cdot 10 \\
2 \cdot 86 \\
2 \cdot 86 \\
2 \cdot 14\end{array}$ & $\begin{array}{l}1 \cdot 02(4) \\
2 \cdot 43(33) \\
2 \cdot 12(56) \\
2 \cdot 21(81) \\
2 \cdot 72(88) \\
3 \cdot 56(82) \\
3 \cdot 00(39) \\
2 \cdot 20(12)\end{array}$ & $\begin{array}{l}1 \cdot 16 \\
2 \cdot 46 \\
2 \cdot 05 \\
2 \cdot 12 \\
2 \cdot 58 \\
3 \cdot 34 \\
2 \cdot 83 \\
2 \cdot 09\end{array}$ & $\begin{array}{l}1 \cdot 69(22) \\
2 \cdot 55(63) \\
2.65(73) \\
3.00(64) \\
2 \cdot 52(33) \\
3 \cdot 32(17) \\
8 \cdot 52(5) \\
-(0)\end{array}$ & $\begin{array}{l}1.92 \\
2 \cdot 58 \\
2 \cdot 57 \\
2 \cdot 86 \\
2 \cdot 38 \\
3 \cdot 14 \\
8 \cdot 22 \\
-\end{array}$ & $\begin{array}{l}1 \cdot 48(38) \\
2 \cdot 62(162) \\
2 \cdot 22(194) \\
2 \cdot 38(229) \\
2 \cdot 40(192) \\
3 \cdot 19(167) \\
3 \cdot 04(80) \\
2 \cdot 16(25)\end{array}$ & $\begin{array}{l}1 \cdot 67 \\
2 \cdot 70 \\
2 \cdot 20 \\
2 \cdot 35 \\
2 \cdot 36 \\
3 \cdot 14 \\
3 \cdot 00 \\
2 \cdot 15\end{array}$ \\
\hline \multirow{2}{*}{$\begin{array}{l}\text { All women } \\
\text { Women - years } \\
\text { of observation }\end{array}$} & $2 \cdot 29(415)$ & $2 \cdot 35$ & $2 \cdot 56(395)$ & $2 \cdot 43$ & $2 \cdot 63(277)$ & $2 \cdot 70$ & & \\
\hline & \multicolumn{2}{|l|}{181475} & \multicolumn{2}{|l|}{154480} & \multicolumn{2}{|l|}{105412} & \multicolumn{2}{|l|}{441367} \\
\hline
\end{tabular}

^Standardised for social class and smoking at recruitment and parity at time of the diagnosis. Observed numbers in parentheses.

ised for age and parity at diagnosis and social class at recruitment, with the total study population as the reference population. All rates quoted are per 1000 women-years. The method of indirect standardisation involved applying stratum specific rates from the total cohort to the person-years of observation in the relevant stratum of each contraceptive group. These expected numbers were used to weight the observed incidence rates. ${ }^{12}$ Confidence intervals were calculated on the assumption that the variance of the log relative risk is equal to the sum of the reciprocals of the observed number of cases in the two groups being compared. Test for linear trends were based on Mantel's method ${ }^{13}$ modified to accommodate standardised data.

\section{Results}

A total of 1087 women had a diagnosis of symptomatic gall bladder disease (cholelithiasis (ICD-8 574) or cholecystitis (ICD-8 575)). The rate of gall bladder disease was not affected by age (Table I).

\section{SMOKING}

Women who smoked were significantly more likely to be diagnosed as having gall bladder disease; rate 2.26 per 1000 women-years among non-smokers, 2.69 per 1000 women-years among moderate smokers (1-15 cigarettes per day), and 2.74 per 1000 women-years in heavy smokers ( $\geqslant 16$ cigarettes per day) (test for trend: $\chi^{2}=7 \cdot 58, \mathrm{p}<0.01$ ) (Table II). The relative risk for all smokers compared with non-smokers was $1 \cdot 19$ (95\% confidence intervals $(95 \% \mathrm{CI}) 1.06$ to $1 \cdot 34)$. Higher rates of symptomatic gall bladder disease were seen among smokers in each oral contraceptive group, although the trend was only significant for never users of the pill.

PARITY

A clear trend of increasing risk with increasing parity was seen in each of the oral contraceptive groups (Table III). The rate of symptomatic gall bladder disease among women of parity 1 was generally twice that of their nulliparous counterparts.

\section{SOCIAL CLASS}

When all women were examined together, there was a significant trend of increasing risk of gall bladder disease with lower social class. Similar trends were found in each of the contraceptive groups, although these did not reach statistic significance (Table IV).

\section{ORAL CONTRACEPTIVE USE}

Compared with never users the relative risk of symptomatic gall bladder disease in current users was $1.15(95 \% \mathrm{CI} 0.99$ to 1.34$)$, and in former users $1.03(95 \%$ CI 0.90 to $1 \cdot 18)$.

\section{Discussion}

The results of this longterm prospective study suggest that cigarette smoking, parity, and possibly lower social class are important risk factors for the development of symptomatic gall bladder disease in women. The overall incidence of symptomatic gall stones among the 20819 women who said they were smokers at the start of

TABLE II Crude and standardised rates (per 1000) of reported first episode of gall bladder disease (ICD-8 574 or 575) by use of oral contraceptives and smoking habits

\begin{tabular}{|c|c|c|c|c|c|c|c|c|}
\hline & \multicolumn{2}{|l|}{ Never users } & \multicolumn{2}{|c|}{ Former users } & \multicolumn{2}{|c|}{ Current users } & \multicolumn{2}{|l|}{ All women } \\
\hline & $\begin{array}{l}\text { Crude rate } \\
\text { (No) }\end{array}$ & $\begin{array}{l}\text { Standardised } \\
\text { rate }^{\star}\end{array}$ & $\begin{array}{l}\text { Crude rate } \\
\text { (No) }\end{array}$ & $\begin{array}{l}\text { Standardised } \\
\text { rate }^{\star}\end{array}$ & $\begin{array}{l}\text { Crude rate } \\
\text { (No) }\end{array}$ & $\begin{array}{l}\text { Standardised } \\
\text { rate }^{\star}\end{array}$ & $\begin{array}{l}\text { Crude rate } \\
\text { (No) }\end{array}$ & $\begin{array}{l}\text { Standardised } \\
\text { rate }\end{array}$ \\
\hline \multirow{2}{*}{$\begin{array}{l}\text { Smoking habits a } \\
0 \\
1-15 \\
\geqslant 16 \\
\text { Test for trend } \\
\text { Relative risk: } \\
\text { Smokers/non- } \\
\text { smokers } \\
\text { (95\% CI) }\end{array}$} & $\begin{array}{l}\text { recruitment } \\
2.04(224) \\
2.60(149) \\
2.91(42)\end{array}$ & $\begin{array}{l}\text { (cigarettes daily } \\
2 \cdot 11 \\
2 \cdot 62 \\
2 \cdot 83\end{array}$ & $\begin{array}{l}2 \cdot 36(191) \\
2 \cdot 80(157) \\
2 \cdot 69(47),\end{array}$ & $\begin{array}{l}2 \cdot 29 \\
2 \cdot 63 \\
2 \cdot 48\end{array}$ & $\begin{array}{l}2.37(129) \\
2.85(111) \\
3.06(37)\end{array}$ & $\begin{array}{l}2.51 \\
2.95 \\
3.06\end{array}$ & $\begin{array}{l}2 \cdot 22(544) \\
2 \cdot 73(417) \\
2 \cdot 86(126)\end{array}$ & $\begin{array}{l}2 \cdot 26 \\
2 \cdot 69 \\
2 \cdot 74\end{array}$ \\
\hline & $\chi^{2}=$ & $5.58, p<0.02$ & & $.92, p>0.05$ & & $(0.94$ to 1.51$)$ & & $9(1.06$ to 1.34$)$ \\
\hline
\end{tabular}

^Standardised for social class at recruitment, age and parity at diagnosis. Observed numbers in parentheses. 
TABLE III Crude and standardised rates (per 1000) of reported first episode of gall bladder disease (ICD-8 574 or 575) by use of oral contraceptives and parity

\begin{tabular}{|c|c|c|c|c|c|c|c|c|}
\hline & \multicolumn{2}{|l|}{ Never users } & \multicolumn{2}{|c|}{ Former users } & \multicolumn{2}{|c|}{ Current users } & \multicolumn{2}{|l|}{ All women } \\
\hline & $\begin{array}{l}\text { Crude rate } \\
\text { (No) }\end{array}$ & $\begin{array}{l}\text { Standardised } \\
\text { rate }^{\star}\end{array}$ & $\begin{array}{l}\text { Crude rate } \\
\text { (No) }\end{array}$ & $\begin{array}{l}\text { Standardised } \\
\text { rate }^{\star}\end{array}$ & $\begin{array}{l}\text { Crude rate } \\
\text { (No) }\end{array}$ & $\begin{array}{l}\text { Standardised } \\
\text { rate }^{\star}\end{array}$ & $\begin{array}{l}\text { Crude rate } \\
\text { (No) }\end{array}$ & $\begin{array}{l}\text { Standardised } \\
\text { rate }\end{array}$ \\
\hline $\begin{array}{c}\text { Parity at diagn } \\
0 \\
1 \\
2+3 \\
\geqslant 4\end{array}$ & $\begin{array}{l}: \\
1 \cdot 20(23) \\
2 \cdot 29(76) \\
2 \cdot 32(245) \\
3 \cdot 01(71)\end{array}$ & $\begin{array}{l}1 \cdot 24 \\
2 \cdot 34 \\
2 \cdot 33 \\
2 \cdot 81 \\
. \cdot 88\end{array}$ & $\begin{array}{l}1.45(9) \\
1.68(28) \\
2.50(255) \\
3.49(103)\end{array}$ & $\begin{array}{l}1 \cdot 53 \\
1.68 \\
2 \cdot 44 \\
3 \cdot 17\end{array}$ & $\begin{array}{l}0.40(3) \\
2.99(47) \\
2.69(182) \\
3.08(45)\end{array}$ & $\begin{array}{l}0 \cdot 48 \\
3 \cdot 31 \\
2 \cdot 80 \\
2 \cdot 97\end{array}$ & $\begin{array}{l}1 \cdot 06(35) \\
2 \cdot 30(151) \\
2 \cdot 48(682) \\
3 \cdot 24(219)\end{array}$ & $\begin{array}{l}1 \cdot 17 \\
2.43 \\
2 \cdot 48 \\
2.96\end{array}$ \\
\hline Test for trend & $\chi^{2}$ & $8, p<0.05$ & & $7, \mathrm{p}>0.01$ & & $\mathrm{p}<0.01$ & & $21 \cdot 89, \mathrm{p}<0.01$ \\
\hline
\end{tabular}

^Standardised for social class and smoking at recruitment and age at diagnosis. Observed numbers in parentheses.

the study was $20 \%$ higher than that found among the 25558 non-smokers. The relation with smoking was most apparent in those women who had never used oral contraception. The rate of symptomatic gall bladder disease roughly doubled once a woman had been pregnant. Women in social classes IV + V had a $25 \%$ greater risk of symptomatic gall bladder disease compared with those in social classes I+II.

The validity of these findings needs careful consideration. This study assessed symptomatic gall bladder disease rather the total occurrence of the condition. It is likely, however, that symptom free and symptomatic gall bladder disease share a common pathogenesis and thus we believe it remains valid to examine factors that predict symptomatic episodes of the illness.

The data are based on reports supplied by the participating general practitioners. Although about $20 \%$ of the women were taken into hospital at the time of their illness, we do not know how many of the episodes were confirmed radiologically or at operation. This apparent lack of confirmatory evidence would be important if the general practitioners diagnosed gall bladder disease differently among patients with particular characteristics - for instance, if they made the diagnosis more often in smokers than nonsmokers. Although possible, we think it unlikely for this to have occurred for risk factors such as smoking and parity. On the other hand it is possible that such a diagnostic suspicion bias accounts for the modest increase in risk among current users but not former users of the pill, although previous work has suggested that this pattern of risk may be due to an accelerating effect of the pill. ${ }^{14}$

By 1987 about $65 \%$ of the women were no longer under observation, mainly because they had moved from the recruiting doctors' practice area. These women were more likely to be younger, of higher social class, and lower parity than those still in the study, but their smoking habits at recruitment were no different. Further- more, the characteristics of pill users no longer observed were similar to never users no longer observed, so comparison between contraceptive groups also remains valid. The smoking data have not been updated since recruitment. Many of the women will have stopped and few will have started smoking. Resulting misclassification will tend to dilute the effect of smoking and so our risk estimates are likely to be underestimates.

We were not able to adjust for the possible confounding effect of body weight as this information has not been collected. A direct relation between body mass index and the risk of gall bladder disease has been described. ${ }^{15}$ Another cohort study has found that pill users tend to be slightly lighter than non-users. ${ }^{16}$ It seems unlikely, therefore, that the ability to adjust for body weight would have materially affected the results that relate to pill use. Also, because smoking tends to be associated with a lower body mass index, our inability to adjust for any confounding due to body weight will have tended to result in an underestimation of the effect of smoking.

Previous studies of the effect of smoking on gall bladder disease have reported conflicting results. The Framingham population cohort study found that compared with non-smokers, those who smoked had a lower rate of clinical gall bladder disease, a difference that reached borderline statistical significance. ${ }^{17}$ The authors were unable, however, to correct for confounding other than by age and sex. Smoking was also found to be associated with a substantial protective effect in a case-control study of symptomatic gall bladder disease, and in a recent case-control study of patients undergoing cholecystectomy. ${ }^{34}$ In both of these studies the control group, hospital inpatients and community controls, had unusually high smoking rates. ${ }^{34}$ Interpretation is therefore problematic.

By contrast, three other studies have found a positive association between cigarette smoking and gall bladder disease. Petitti et al found a

TABLE IV Crude and standardised rates (per 1000) of reported first episode of gall bladder disease (ICD-8 574 or 575) by use of oral contraceptives and social class

\begin{tabular}{|c|c|c|c|c|c|c|c|c|}
\hline & \multicolumn{2}{|l|}{ Never users } & \multicolumn{2}{|c|}{ Former users } & \multicolumn{2}{|c|}{ Current users } & \multicolumn{2}{|l|}{ All women } \\
\hline & $\begin{array}{l}\text { Crude rate } \\
\text { (No) }\end{array}$ & $\begin{array}{l}\text { Standardised } \\
\text { rate }^{\star}\end{array}$ & $\begin{array}{l}\text { Crude rate } \\
\text { (No) }\end{array}$ & $\begin{array}{l}\text { Standardised } \\
\text { rate }^{\star}\end{array}$ & $\begin{array}{l}\text { Crude rate } \\
\text { (No) }\end{array}$ & $\begin{array}{l}\text { Standardised } \\
\text { rate }^{\star}\end{array}$ & $\begin{array}{l}\text { Crude rate } \\
\text { (No) }\end{array}$ & $\begin{array}{l}\text { Standardised } \\
\text { rate }\end{array}$ \\
\hline \multicolumn{9}{|c|}{ Social class at recruitment: } \\
\hline $\begin{array}{l}\text { I+II } \\
\text { III } \\
\text { IV + V }\end{array}$ & $\begin{array}{l}1 \cdot 99(85) \\
2 \cdot 34(234) \\
2 \cdot 48(91)\end{array}$ & $\begin{array}{l}2 \cdot 07 \\
2 \cdot 42 \\
2 \cdot 49\end{array}$ & $\begin{array}{l}2 \cdot 50(83) \\
2 \cdot 30(205) \\
3 \cdot 21(97)\end{array}$ & $\begin{array}{l}2 \cdot 40 \\
2 \cdot 19 \\
2 \cdot 96\end{array}$ & $\begin{array}{l}2 \cdot 14(50) \\
2 \cdot 68(160) \\
2 \cdot 97(60)\end{array}$ & $\begin{array}{l}2 \cdot 26 \\
2 \cdot 75 \\
2 \cdot 95\end{array}$ & $\begin{array}{l}2 \cdot 20(218) \\
2 \cdot 40(599) \\
2 \cdot 84(248)\end{array}$ & $\begin{array}{l}2 \cdot 22 \\
2 \cdot 41 \\
2 \cdot 77\end{array}$ \\
\hline Test for trend & \multicolumn{2}{|c|}{$\chi^{2}=2.52, p<0.05$} & \multicolumn{2}{|c|}{$\chi^{2}=2.09, p<0.05$} & \multicolumn{2}{|c|}{$\chi^{2}=1.92, p>0.05$} & \multicolumn{2}{|c|}{$\chi^{2}=5.72, p<0.02$} \\
\hline
\end{tabular}

* Standardised for social class at recruitment age, and parity at diagnosis.

Excludes 22 women whose social class was unknown; observed numbers in parentheses. 
statistically significant increased risk of clinical gall bladder disease among smokers in a case control study of female twins ${ }^{7}$ and Layde et al found an increased risk in a cohort study of women attending British family planning clinics. ${ }^{18}$ The third study found a direct relation between smoking and clinical gall bladder disease among men but not among women. ${ }^{6}$

Two large population surveys with ultrasound to detect gall bladder disease have also shown an increase in the overall prevalence of gall bladder disease among male but not female smokers, although the findings were not clear cut. ${ }^{1920}$ For example, the increased risk found by Jorgensen showed only a weak dose response relation, ${ }^{19}$ and the effect found by the Rome Group for Epidemiology and Prevention of Cholelithiasis was reduced after adjustments for confounding factors. ${ }^{20}$

On balance the better controlled studies have shown that cigarette smoking promotes gall bladder disease. At present, we do not know how smoking might promote either gall stone formation or the development of symptoms. Smoking could affect gall bladder pathophysiology - for example, by stimulating mucin secretion and thus promoting cholesterol monohydrate nucleation - a critical step in gall stone formation. ${ }^{21}$ Certainly smoking stimulates mucin secretion by the respiratory tract mucosa, probably by a direct irritant effect. Recent evidence suggests, however, that nicotine inhibits gall bladder bile mucin concentration. ${ }^{22}$ Alternatively, smoking could exert an effect on gall bladder contractility, possibly by inhibition of prostaglandin synthesis. There is, however, conflicting evidence regarding the effect of inhibitors of prostaglandin synthesis on gall bladder contractility. ${ }^{23} 24$

Interest in whether parity and the use of oral contraceptives are associated with the development of symptomatic gall bladder disease has been stimulated by the consistent finding that women of reproductive age have a higher incidence of symptomatic and symptom free gall bladder disease compared with men of the same age. Previous reports have found that parity did not increase the risk of symptomatic gall bladder disease, increased the risk after a single pregnancy, or only increased the risk after several pregnancies. Thijs and colleagues recently reviewed the results of all controlled studies on this issue and noted that a statistically significant positive association between parity or pregnancy was found in 26 of 42 studies. $^{8}$ Nevertheless, the most recent large epidemiological study to consider this issue, the American Nurses Health study found no relation between parity and the development of clinical gall stone disease. ${ }^{25}$ Inconsistencies in the results of previous studies may be due to variations in the level of symptom recall, patient complaint, or consultation with medical practitioners and type of investigation performed on the various study populations. An alternative explanation might be that pregnancy increases the risk of gall stone formation only transiently. Thijs et al have postulated that pregnancy exerts an effect that disappears after about five years. ${ }^{8}$ Some studies they suggest may have failed to detect an effect of parity because they did not concentrate on this risk period. ${ }^{8}$

Pregnancy is often associated with two definite gall bladder abnormalities - namely, reduced gall badder contractility, which is believed to be due to raised progesterone concentrations, and the development of biliary sludge. ${ }^{8}$ Biliary sludge contains cholesterol crystals, calcium bilirubinate granules, and very high concentrations of mucin glycoprotein, a putative nucleating agent. ${ }^{26}$ Many studies suggest that sludge formation is a marker of gall stone formation. A recent Italian study showed that during pregnancy or the puerperium $41 \%$ of women develop biliary sludge. ${ }^{27}$ Progression to gall stone formation in a sizeable proportion of these subjects may be the mechanism whereby pregnancy predisposes to gall stone formation.

Early studies of the effects of oral contraceptives suggested that the pill was associated with a large increase in risk of symptomatic gall bladder disease. ${ }^{28}$ Most recent studies have, however, failed to confirm this. Scragg et al in a casecontrol study found that ever use of the pill was associated with an increased risk of symptomatic gall bladder disease in women younger than 29 years and a reduced risk of symptomatic gall bladder disease in older women. ${ }^{29}$ We were unable to find such a relation. Our results suggest that at most, current use of the pill is associated with only a small increase in risk of clinical gall bladder disease, which disappears after stopping the pill. If it is not due to diagnostic suspicion bias then postulated mechanisms might include changes in gall bladder contractility associated with the progesterone content, ${ }^{9}$ or increased cholesterol saturation of bile due to the oestrogen content. ${ }^{10}$

In summary, cigarette smoking, parity, and possibly lower social class were associated with an increased risk of symptomatic gall bladder disease in women. The effect of smoking was most apparent in those who had never used oral contraception. Use of the oral contraceptive pill was associated with a small increase in risk that was limited to current users.

We thank the 1400 general practitioners who contributed data to the study. The study currently receives support from the British Heart Foundation, the Imperial Cancer Research Fund, Schering GD Searle and Co. We also thank Mrs Carole Weaver for her excellent secretarial assistance.

1 Paumgartner G, Sauerbruch T. Gall stones: pathogenesis. Lancet 1991; 338: 1117-21.

2 Lee SP, Maher K, Nicholls JF. Origin and fate of biliary sludge. Gastroenterology 1988; 94: 170-6.

3 Pastides H, Tzonou A, Trichopoulos D, Katsouyanni K, Trichopoulou A, Kefalogiannis N, Manousos O. A casecontrol study of the relationship between smoking, diet, and gall gladder disease. Arch Intern Med 1990; 150: 1409-12.

4 Rhodes M, Venables CW. Symptomatic gall stones - a disease of non-smokers? Digestion 1991; 49: 221-6.

5 Baron JA, Logan RFA. Smoking and gall stones. In: Wald N, Baron JA, eds. Smoking and hormone-related diseases. Oxford: Oxford University Press, 1990.

6 Diehl AK, Hafner SM, Hazada HP, Stern MP. Coronary risk factors and clinical gall bladder disease: an approach to the prevention of gall stones? Am $\mathcal{F}$ Public Health 1987; 77: 841-5.

7 Petitti DB, Friedman GD, Klatsky AL. Association of a history of gall bladder disease with a reduced concentration history of gall bladder disease with a reduced concentration
of high-density lipoprotein cholesterol. $N$ Engl F Med 1981; 304: 1396-8.

8 Thijs C, Knipschild P, Leffers P. Pregnancy and gallstone disease: an empiric demonstration of the importance of specification of risk periods. Am $\mathcal{F}$ Epidemiol 1991; 134: 18695.

9 Ryan JP, Pelleccia D. Effect of progesterone on guinea-pig gall bladder motility in vitro. Gastroenterology 1982; 83: 81-3. 
10 Kern F, Everson GT. Contraceptive steroids increase cholesterol in bile: mechanisms of action. $\mathcal{F}$ Lipid Res 1987; 28: $828-39$.

11 Myers SI. Effect of oestrogen on rabbit gall bladder prostaglandin biosynthesis. F Surg Res 1985; 38: 630-4.

12 Royal College of General Practitioners. Oral Contraceptives and Health. London: Pitman Medical; 1974.

13 Mantel N. Chi-square tests with one degree of freedom. Extension of the Mantel-Haenszel procedure. Fournal of the Extension of the Mantel-Haenszel procedure.
American Statistical Association 1963; 58: 690 .

14 Wingrave SJ, Kay CR. Oral contraceptives and gall bladder disease. Royal College of General Practitioners' Oral disease. Royal College of General Practicic

15 Diehl AK. Epidemiology and natural history of gall stone disease. Gastroenterol Clin North Am 1991; 20: 1-19.

16 Vessey MP, Doll R, Peto R, Johnson B, Wiggins P. A long term follow up study of women using different methods of contraception - An interim report. 7 Biosoc Sci 1976; 8: 373427.

17 Friedman DB, Friedman GD, Klatsky AL. The epidemiology of gall bladder disease: observations in the Framingham Study. Fournal of Chronic Diseases 1966; 19: 273-92.

18 Layde PM, Vessey MP, Yeates D. Risk factors for gall bladder disease: a cohort study of young women attending family disease: a cohort study of young women attending family
planning clinics. 7 Epidemiol Community Health 1982; 36: planning 274 .

19 Jorgensen T. Gall stones in a Danish population. Relation to weight, physical activity, smoking, coffee consumption and diabetes mellitus. Gut 1989; 30: 528-34.

20 GREPCO (Rome Group for Epidemiology and Prevention of Cholelithiasis). The epidemiology of gallstone disease in Rome. Part II. Factors associated with the disease. Hepatology 1988; 8: 907-13.

21 Levy P, Smith BF, LaMont JT. Human gall bladder mucin accelerates in vitro nucleation of cholesterol in artificial bile. Gastroenterology 1984; 87: 270-5.

22 Rhodes M, Ziilstra FJ, Bradburn DM, Srivastava ED, Russell MAH, Van Blanknstein M, et al. Concentration of gall bladder bile mucin is reduced by nicotine. Gut 1992; 33: bladder

23 O'Donnell LDJ, Wiben P, Guest P, Catnach SM, McLean A, Wickham JEA, et al. Indomethacin and postprandial gall

24 Murray FE, Stinchcombe SJ, Hawkey CJ. Effect of indomethacin and misoprostol on fasting gall bladder volume and meal-induced gall bladder contractility in humans. Dig Dis Sci 1992; 33: 1228-31.

25 MacLure KM, Hayes KC, Colditz GA, Stampfer MJ, Speizer FE, Willett WC. Weight, diet and the risk of symptomatic gall stones in middle-aged women. $N$ EnglF Med 1989; 321: 563-9.

26 Lee SP, Nicholls JF. Nature and composition of biliary sludge. Gastroenterology 1986; 90: 677-86.

27 Maringhini A, Ciambra M, Baccelliene P. Sludge, stones and pregnancy. Gastroenterology 1988; 95: 1160-1.

28 Boston Collaborative Drug Surveillance Programme. Oral contraceptives and venous thromboembolic disease, surgically confirmed gall bladder disease, and breast tumours. Lancet 1973; i: 1399-404.

29 Scragg RKR, McMichael AJ, Seamark RF. Oral contraceptives, pregnancy, and endogenous oestrogen in gall stone disease: A case-control study. BMF 1984; 288: 1795-9. 